\title{
Gulf states plan for nuclear future
}

While Iran grabs international headlines for its controversial nuclear programme, ambitious plans for an atomic roll-out on the other side of the Gulf are quietly under way. Non-proliferation experts are already voicing concern.

Major oil-producing states, including Saudi Arabia, the United Arab Emirates (UAE) and Bahrain, are taking steps to develop civilian nuclear power. Concurrently, the Gulf Cooperation Council (GCC), a trade bloc of the six Arab states in the region, is working with the International Atomic Energy Agency (IAEA) to erect a research reactor on the peninsula. Nearly everyone in the Gulf has declared some interest in nuclear power over the past two years, says Mustafa Alani, a senior consultant with the Gulf Research Centre, an independent think tank in Dubai, UAE. "There is a fever in the region."

Interest in nuclear power is on the rise worldwide, but the Gulf may be better situated than most to actually build reactors. Whereas Western utilities struggle to raise the billions needed for a power plant, the cash-flush Gulf states have more than enough money, says Seth Grae, chief executive of Thorium Power, a consultancy on nuclear power based in McLean, Virginia. "Right now, the Gulf region represents one of the most exciting and promising nuclear markets in the world."

Grae says that the nuclear fever is driven by the region's rapidly expanding economies and the need for fresh water, for which energyintensive desalination is the best option. But some non-proliferation experts say that fear of Iran, which may be close to developing a nuclear weapon, is the real reason behind the growing interest. "States are not driven to build reactors solely based on economic concerns," says Jill Parillo, deputy director for security programmes at Physicians for Social Responsibility, an advocacy group based in Washington DC. "It's a perceived security assurance."

It may seem strange that a region flush with oil and natural gas - not to mention the solarenergy potential - would even consider building nuclear power stations. Nuclear power plants are enormously expensive to build — recent estimates run at US\$7 billion per plant. And there are time-consuming, political complications. A nation with nuclear power must introduce legislation to address liability and safety concerns, for example, and an independent regulatory body to oversee plant operations.

Yet nuclear power makes sense for the Gulf states, says Hans-Holger Rogner, the head

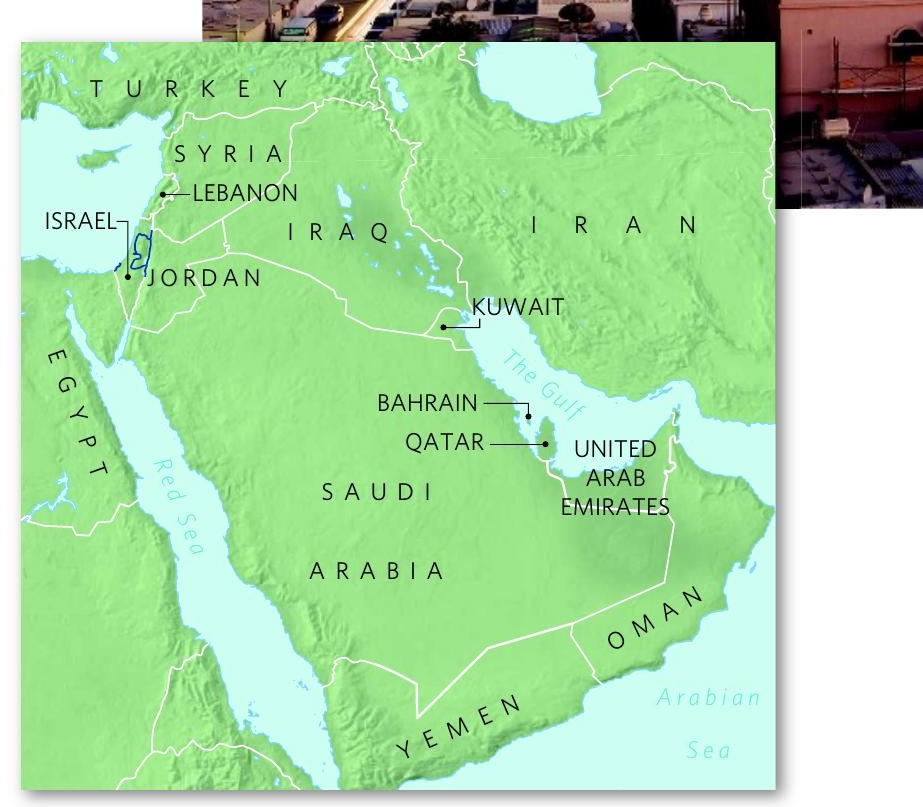

\section{Brazil braced for unexpected oil wealth}

At a time when most countries are struggling with ageing oilfields, Brazil is debating a new future as an oil exporter following the recent discovery of world-class reservoirs off its coast.

President Luiz Inácio Lula da Silva (Lula) has appointed a cabinet-level committee to come up with recommendations on proposals such as the creation of a state-owned company to manage the development, and a national 'rainy-day' fund for collecting and disbursing the revenue. The committee is expected to report later this week, but Lula is said to favour both approaches, and says that he wants to see the money invested in education and social programmes.

Some experts caution that attempts to consolidate control over the new oil resources could effectively undercut Brazil's biggest asset, Petróleo Brasileiro (Petrobras), the governmentcontrolled oil company that has pioneered exploration of the new fields. Georges Landau, who heads São Paulo-based energy consultancy Prismax Consultoria, says the government could make a good case for increasing its share of the revenue now that Petrobras has confirmed there is oil to be tapped. And Brazil should create a better system for handling offshore oil revenue, much of which is currently squandered by Rio de Janeiro state, he says.

But Landau thinks the proposal to create a state-owned company is a political ploy to ensure control, driven by the fact that many foreign investors hold shares in Petrobras. In theory, the new company would manage the development while
Petrobras and others do the drilling. Landau says such a move could damage Petrobras and ultimately delay the development. "That's what I fear will happen, and it will be a disaster, really. It's selfdestructive."

Others are less pessimistic. "I don't think Brazil's plan is to go down the same nationalistic route of other countries in the region" (such as Bolivia, which nationalized its energy industry and shut down foreign firms), says Roger Tissot, an expert on Latin America based in British Columbia, Canada. "I think 


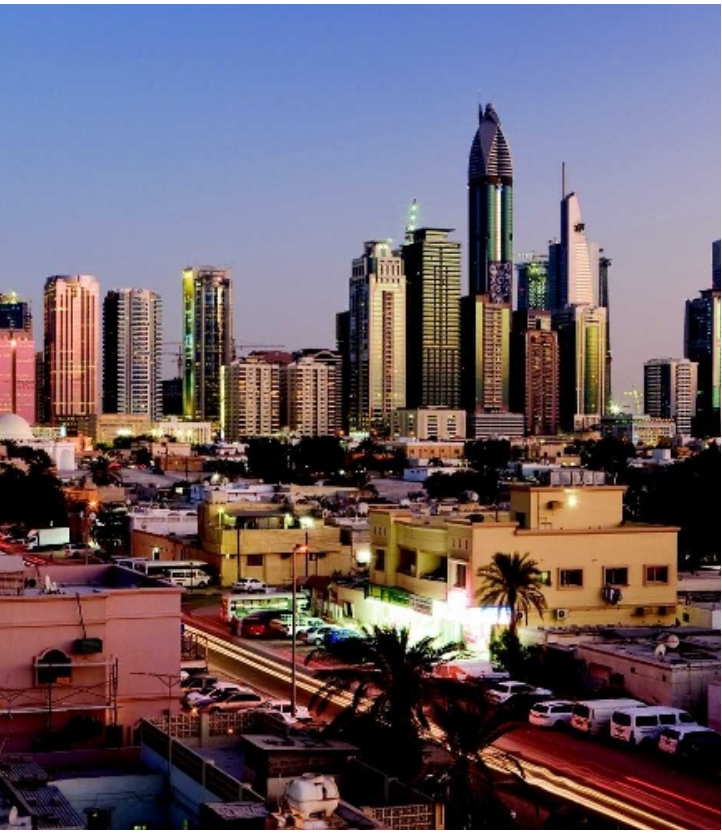

The speed of development in Dubai makes many think its nuclear power project will also be rapid.

of planning and economic studies at the IAEA, which is responsible for both overseeing nuclear safeguards and promoting the development of nuclear power. The region faces unprecedented growth over the coming decade. The UAE alone expects its electricity needs to almost quadruple, rising from around 15 gigawatts (thousand megawatts) in 2006 to nearly 40 gigawatts in 2020 . Part of that demand is driven by the UAE's rapid economic development, but demand for fresh water, which will be desalinated using energyintensive reverse osmosis, is also a major factor. The need for electricity could be met in part by burning fossil fuels, but their anticipated future price abroad makes that option uneconomical, Rogner says. "The oil and gas the Gulf states produce are worth far more on the international market than if they burn them at home."

The UAE has progressed furthest in its plans to develop nuclear power. Earlier this year, the small, oil-rich nation penned a cooperative agreement with France to begin nuclear development, and it is looking at a bid from French companies Areva, Suez and Total to build and operate two 1,600-megawatt reactors on islands off its coast. At the same time, it is enacting legislation on nuclear issues and setting up an independent regulatory body to license and oversee its plants. "They're taking it very seriously," says Grae, whose firm consults with the UAE government on its nuclear plans.

Some are concerned about the UAE programme's rapid development. The tiny state is famous for importing foreign talent to build its roads and bridges, and it looks as though nuclear will be no exception. “They're apparently talking about just buying in regulators from other countries," says Charles Ferguson of the Council on Foreign Relations, a think tank based in Washington DC. Ferguson says that these foreign regulators would face "enormous pressure" from the government if they tried to shut down a reactor for safety reasons.

Grae counters that the UAE already has a proven record of importing international talent to operate independent institutions. Dubai's International Financial Centre, for example, is administered according to international 'common law' and has its own courts staffed by foreign judges. "The UAE has some real examples of regulatory independence," Grae says.

Like many states in the region, the UAE has

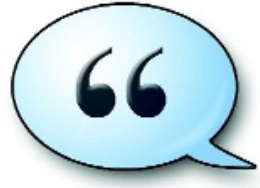

HAVE YOUR SAY

Comment on this or any of our News stories, online. www.nature.com/news signed up to the international Nuclear NonProliferation Treaty, a document that promises aid for civilian programmes if countries give up their right to nuclear arms. In addition, it and many other GCC states have announced that they will not develop the nuclear technologies of most concern: uranium enrichment and spent-fuel reprocessing. Both technologies can be used to manufacture reactor fuel, but they can also be used to refine weapons-grade nuclear material. Rogner says he is satisfied that the Gulf states are not a danger. "A nuclear power plant per se is not a proliferation risk," he says.

Grae says that he believes economics is the sole driver behind the Gulf's push for nuclear power. "What I am seeing in the UAE is that this has zero to do with security," he says.

But Parillo has her doubts. Creating the technological basis for a civilian programme will also be of some use should the states ever need to develop nuclear weapons, she says. Building and operating plants will help nations develop expertise in areas such as reactor physics and the handling of nuclear materials. "This is the first step on the way to developing a dual-use capability."

Alani adds that it is no coincidence that the Gulf's nuclear renaissance began in earnest two years ago. In the spring of 2006, the IAEA announced that Iran was enriching uranium without the agency's approval. The Gulf states view Iran as an expansionist and interventionist regime, he says, and the international community's failure to control its programme set off alarm bells. The message to many states was clear, he says: "One has to start a civilian programme to start narrowing the gap."

Geoff Brumfiel
Brazil is being very professional and very serious in its approach."

Tissot points out that Brazil is well within its rights to rethink the structure of its industry going forward, and he credits the government with looking to Norway as a potential model. Norway has a national fund to manage its oil revenue in perpetuity, he says, and at one time had a state-owned company - separate from Statoil, the main Norwegian oil producer - managing the development of its North Sea resources.

Petrobras controls some $95 \%$ of the nation's oil production, which is largely offshore. The new discoveries, some of which lie directly below current reservoirs south of Rio de Janeiro, are located several thousand metres below sea level in more than 2,000 metres of water. They have been dubbed 'pre-salt' fields because they also lie below a 2,000-metre layer of salt.

It's not yet clear just how much oil can be recovered, in part because nobody has ever drilled in such conditions. But some experts are setting the potential reserves at 80 billion barrels or more. If true, this would take Brazil past Russia and into the league of some of the Middle Eastern oil superpowers. Petrobras has confirmed a 5-billion to

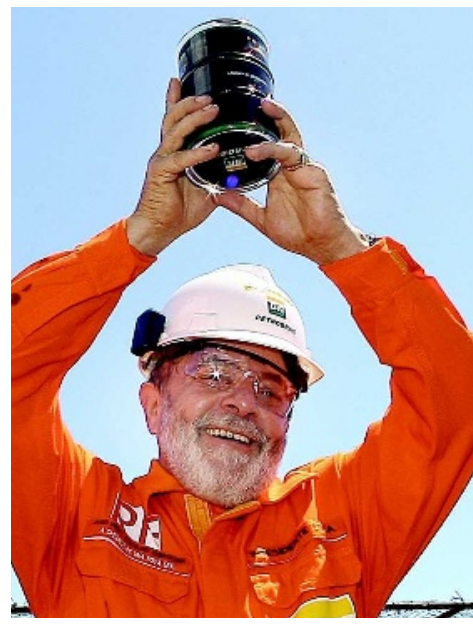

President Lula brandishes a first sample from Brazil's latest oilfield. 8-billion-barrel estimate for one of the fields, but has not released official estimates for many others.

Matthew Shaw, a Latin American analyst for Wood Mackenzie, a consultancy firm in Edinburgh, UK, says that Petrobras and its partners have drilled two wells into one field and one into each of seven other fields; ExxonMobil is getting ready to drill its own wells into an adjacent area.

"I've seen estimates of 50 billion barrels, and I've seen estimates of 80 billion barrels, but nobody knows," says Shaw. "It's definitely in the tens of billions of barrels, but there's no point in guessing now." Jeff Tollefson 